\title{
Nrf2-Mediated Antioxidant Activity of the inner bark extracts obtained from Tabebuia rosea (Bertol) DC and Tabebuia
} chrysantha (JACQ) G. Nicholson. [version 1; peer review: 2 approved]

\author{
Sandra C. Garzón-Castaño1,2, Iván A. Lopera-Castrillón1, \\ Francisco J. Jiménez-González (ii)3, Fernando Siller-López², Luz A. Veloza³, \\ Juan Carlos Sepúlveda-Arias (D1) \\ ${ }^{1}$ Grupo Infección e Inmunidad, Facultad de Ciencias de la Salud, Universidad Tecnológica de Pereira, Pereira, Risaralda, 660003, \\ Colombia \\ ${ }^{2}$ Grupo de Biomedicina, Facultad de Medicina, Fundación Universitaria Autónoma de las Américas, Pereira, Risarala, 660003, \\ Colombia \\ ${ }^{3}$ Grupo Polifenoles, Facultad de Tecnologías, Universidad Tecnológica de Pereira, Pereira, Risaralda, 660003, Colombia
}

V1 First published: $16 \operatorname{Dec} 2018,7: 1937$

https://doi.org/10.12688/f1000research.17165.1

Latest published: 12 Feb 2019, 7:1937

https://doi.org/10.12688/f1000research.17165.2

\section{Abstract}

Background: Several ethnobotanical and ethnopharmacological studies have shown the therapeutic potential of plants from the genus Tabebuia, which have long been used in traditional medicine in rural areas of South America, for the treatment of several human diseases. This study aimed to evaluate the Nrf2-mediated antioxidant activity of the inner bark extracts obtained from Tabebuia rosea and Tabebuia chrysantha.

Methods: The antioxidant activity of extracts obtained from the inner bark of $T$. rosea and $T$. chrysantha was evaluated using the Oxygen radical absorbance capacity (ORAC) technique. The effect of extracts on the viability of HepG2 cells was determined using the 3-(4,5dimethylthiazol-2-yl)-2,5-diphenyl tetrazolium bromide (MTT) method. The translocation of Nrf2 to the nucleus after exposure of HepG2 cells to the extracts and controls (a-lipoic acid, curcumin and hydrogen peroxide) was evaluated using the Nrf2 transcription factor kit. Induction of the Nrf2-mediated antioxidant response gene (NQO1) was evaluated by real-time PCR.

Results: The ethyl acetate extract obtained from both species displayed the highest ORAC activity $(12,523$ and 6,325 $\mu$ moles Eq Trolox/g extract, respectively). In addition, the extracts had the ability to activate and to translocate Nrf2 to the nucleus, as well as to induce the expression of NQO1.

Conclusion: These results indicate that the ethyl acetate extracts

\section{Open Peer Review}

Approval Status

1 2

version 2

(revision)

12 Feb 2019

version 1

16 Dec 2018

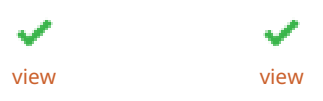

1. Jaime Martin-Franco (D), Universidad del

Cauca, Popayán, Colombia

2. Silvia Quesada, University of Costa Rica

(UCR), San Pedro, Costa Rica

Any reports and responses or comments on the article can be found at the end of the article. 
obtained from the inner bark of $T$. chrysantha and $T$. rosea have an important antioxidant effect mediated by Nrf2 activation, and could be used as a new source of natural antioxidants.

\section{Keywords}

Tabebuia chrysantha, Tabebuia rosea, Bignoniaceae, extracts, Nrf2, antioxidant agents.

\section{Corresponding author: Juan Carlos Sepúlveda-Arias (jcsepulv@utp.edu.co)}

Author roles: Garzón-Castaño SC: Conceptualization, Formal Analysis, Funding Acquisition, Investigation, Methodology, Validation, Visualization, Writing - Original Draft Preparation; Lopera-Castrillón IA: Formal Analysis, Investigation, Methodology, Validation; Jiménez-González FJ: Formal Analysis, Investigation, Methodology, Validation; Siller-López F: Conceptualization, Formal Analysis, Methodology, Writing - Original Draft Preparation; Veloza LA: Conceptualization, Methodology, Resources, Writing - Review \& Editing; Sepúlveda-Arias JC: Conceptualization, Funding Acquisition, Project Administration, Supervision, Validation, Visualization, Writing Review \& Editing

Competing interests: No competing interests were disclosed.

Grant information: This study was supported by Patrimonio Autónomo Fondo Nacional de Financiamiento para la Ciencia, la Tecnología y la Innovación, Francisco José de Caldas, Contrato RC-0572-2012-Bio-Red-Co-CENIVAM, Universidad Tecnológica de Pereira (Project 9-

14-5), Fundación Universitaria Autónoma de las Américas and Sistema General de Regalías de Colombia (Código BPIN 2012000100050). The funders had no role in study design, data collection and analysis, decision to publish, or preparation of the manuscript.

Copyright: @ 2018 Garzón-Castaño SC et al. This is an open access article distributed under the terms of the Creative Commons Attribution License, which permits unrestricted use, distribution, and reproduction in any medium, provided the original work is properly cited.

How to cite this article: Garzón-Castaño SC, Lopera-Castrillón IA, Jiménez-González FJ et al. Nrf2-Mediated Antioxidant Activity of the inner bark extracts obtained from Tabebuia rosea (Bertol) DC and Tabebuia chrysantha (JACQ) G. Nicholson. [version 1; peer review: 2 approved] F1000Research 2018, 7:1937 https://doi.org/10.12688/f1000research.17165.1

First published: 16 Dec 2018, 7:1937 https://doi.org/10.12688/f1000research.17165.1 
Abbreviations used: AAPH: 2,2'-Azobis (2-amidinopropane) dihydrochloride; ALA: Alpha-lipoic acid; CUR: Curcumin; ORAC: Oxygen radical absorbance capacity; MTT: 3-(4,5-dimethylthiazol-2-yl)-2,5-diphenyl tetrazolium bromide.

\section{Introduction}

Nature's compounds reveal a great diversity of chemical structures and physicochemical properties, as well as biological ones. Over the years, plants have been used for the treatment of various diseases, including those of inflammatory origin, such as arthritis, obesity, and cancer. Plants of the genus Tabebuia belong to the Bignoniaceae family, which is composed of about 120 genera with 827 species, and is considered the second most diverse family of species of neotropical woody plants in dry forests ${ }^{1}$. There are reports on the presence of chemical compounds-including quinones and phenols, among others-in this family ${ }^{2,3}$. The Tabebuia genus comprises about 100 species of trees and shrubs, mainly distributed from Mexico to several regions of Central and South America, which have been used in traditional medicine. Plants of this genus are an important source of bioactive molecules such as: naphthoquinones; quinones; phenols; and molecules with anti-inflammatory, antioxidant, anti-microbial and anti-proliferative activity ${ }^{4-8}$.

A large number of chemical compounds exert their antioxidant effects through the activation of key transcriptional regulation mechanisms, such as the transcription factor Nrf2 (nuclear factor erythroid 2-related factor 2) ${ }^{9}$. Under normal physiological conditions, this factor is in the cytoplasm inhibited by Keap1 (Kelch ECH associating protein 1), which leads to its degradation ${ }^{10}$. In cells exposed to oxidative stress, Nrf2 is not targeted for ubiquitin-dependent degradation. Instead, it is released and translocated to the nucleus, where it activates its antioxidant response through binding to Antioxidant Response Elements (ARE sites), allowing the coordinated expression of more than 200 detoxifying enzymes and antioxidants, such as $\mathrm{NAD}(\mathrm{P}) \mathrm{H}$ quinone oxidoreductase (NQOl) and heme oxygenase 1 (HO-1), among others ${ }^{11-14}$. The aim of this study was to evaluate the Nrf2mediated antioxidant activity of extracts obtained from the inner bark of Tabebuia rosea and Tabebuia chrysantha in HepG2 cells.

\section{Methods}

Plant material and extract preparation

The inner bark from $T$. rosea (Bertol.) DC and T. chrysantha (JACQ) G. Nicholson were collected at Universidad Tecnológica de Pereira campus in April 2011. The plants were identified at the Colombian National Herbarium (Voucher No. COL 582577 for $T$. rosea and COL 587611 for $T$. chrysantha). The collection and processing of the material were covered by the collection permission number 1133/2014, issued by the National Environmental Licensing Authority (ANLA) of Colombia.

Extracts were obtained as previously described ${ }^{6}$. Plant material (inner bark from $T$. chrysantha and $T$. rosea) was dried and macerated in methanol analytical grade (14 L)for $48 \mathrm{~h}$. This was followed by homogenization, filtration, and concentration under vacuum using a vacuum rotary evaporator (Heidolph, Laborota model) at $40{ }^{\circ} \mathrm{C}$ to obtain the crude extract. This procedure was repeated three times. Crude extracts were dissolved in $400 \mathrm{~mL}$ of distilled water, and underwent liquid-liquid extraction with increasing polarity solvents (solvent volume $1.6 \mathrm{~L}$ ): $n$-hexane, chloroform $\left(\mathrm{CHCl}_{3}\right)$, ethyl acetate (EtOAc), and $n$-butanol (all solvents were analytical grade). Each extract was vacuum dried by vacuum rotary evaporator obtaining the following mass for each extract: $n$-hexane $(0.3 \mathrm{~g})$, chloroform $(1.2 \mathrm{~g})$, ethyl acetate $(3.7 \mathrm{~g})$, $n$-butanol (12.5 g) and aqueous (21.7 g). Endotoxin levels in the extracts were assayed using the Limulus Amebocyte Lysate Test, E-Toxate Kit (Sigma Chemical Co, Saint Louis, MO, USA, Cat No. ET0200-1KT). All samples were negative for the presence of endotoxins (detection limit $0.05-0.1 \mathrm{EU} / \mathrm{mL}$ ). The extracts were kept refrigerated at $4{ }^{\circ} \mathrm{C}$ in amber tubes protected from light, heat, air and moisture. For each one of the biological assays, the extracts were dissolved in $0.1 \%$ DMSO (Dimethyl sulfoxide, Merck, Darmstadt, Germany, Cat No. 1029521000).

\section{Preliminary phytochemical screening}

The preliminary phytochemical screening was performed using selective derivatization reactions for the characterization of secondary metabolites present in the $n$-hexane, chloroform, ethyl acetate and $n$-butanol extracts obtained from inner bark, as previously reported for $T$. rosea ${ }^{6}$. The extracts were evaluated using normal and reverse phase thin layer chromatography (TLC). Chromatographic plates were revealed with aluminum chloride $\left(\mathrm{AlCl}_{3}\right.$, Sigma Chemical Co, Saint Louis, MO, USA, Cat No. 563919-25G) and ferric chloride $\left(\mathrm{FeCl}_{3}\right.$, Sigma Chemical Co, Saint Louis, MO, USA, Cat No. 157740-1KG ) for detection of flavonoids, phenols and phenolic acids; potassium hydroxide (KOH, Merck, Darmstadt, Germany, Cat No. 1050331000) in analytical grade ethanol for detection of anthrones, quinones and coumarins; oleum (Sigma Chemical Co, Saint Louis, MO, USA, Cat No. 778990-500ML) for detection of sesquiterpenic lactones; and the Liebermann-Burchard reagent for detection of terpenes and steroids.

\section{Total phenolic content}

The total phenolic content of each extract was determined according to the Folin-Ciocalteu colorimetric method ${ }^{15}$, using gallic acid as standard. Briefly, Folin-Ciocalteu's reactive (Merck, Darmstadt, Germany, Cat No. 1090010100) was diluted 10-fold with distilled water. $25 \mu \mathrm{L}$ of the samples $(1 \mathrm{mg} / \mathrm{mL})$ were added to the Folin-Ciocalteu's reactive. After the addition of $\mathrm{Na}_{2} \mathrm{CO}_{3}$ $(20 \%)$, the reaction was maintained at room temperature (RT) in the dark for $30 \mathrm{~min}$, and absorbance was measured at $760 \mathrm{~nm}$ in a Shimadzu UV-1700 spectrophotometer. Gallic acid $(0.25-5 \mathrm{mg} / \mathrm{mL})$ was used to generate a standard curve $\left(\mathrm{y}=0.101 \mathrm{x}+0.086 ; R^{2}=0.996\right)$. Results are presented as $\mathrm{mg}$ gallic acid equivalents per $\mathrm{g}$ of extract (mg GAE/g extract). All experiments were performed in triplicate.

\section{Oxygen radical absorbance capacity (ORAC)}

Oxygen radical absorbance capacity was determined using the method described by $\mathrm{Ou}$ et al, with some modifications ${ }^{16}$. 2,2'-Azobis (2-amidinopropane) dihydrochloride (AAPH) and sodium fluorescein stock solutions were prepared in a $75 \mathrm{mM}$, pH 7.0 phosphate buffer solution. $31 \mu \mathrm{L}$ of each sample were diluted in $187 \mu \mathrm{L}$ of fluorescein $(120 \mathrm{nM})$ and incubated at $37{ }^{\circ} \mathrm{C}$ for $10 \mathrm{~min}$. The reaction was started by the addition of $31 \mu \mathrm{L}$ of 
AAPH $(143 \mathrm{mM})$ to reach a final volume of $249 \mu \mathrm{L}$ per well. Extracts were evaluated at 10,15 , and $20 \mu \mathrm{g} / \mathrm{mL}$. A Trolox ${ }^{\circledR}$ standard curve was prepared $(10,20,40$, and $60 \mu \mathrm{M})$. Changes in fluorescence were measured with a Varian Cary Eclipse 1.1 fluorescence spectrophotometer at 2 min intervals for $120 \mathrm{~min}$ with emission and excitation wavelengths of 515 and $493 \mathrm{~nm}$, respectively. The excitation slit was $5 \mathrm{~nm}$, as was the emission $\operatorname{slit}^{17,18}$. The antioxidant capacity was calculated as the area under the curve (AUC) ${ }^{19}$ and expressed as $\mu$ mol Trolox ${ }^{\circledR}$ equivalents per $g$ of extract ( $\mu \mathrm{mol} \mathrm{TE} / \mathrm{g}$ of extract).

\section{Cell culture}

Human hepatocarcinoma cell line (HepG2; ATCC; CRL11997) was purchased from American Type Culture Collection (ATCC, Rockville, MD, USA) and cultured with Dulbecco's Modified Eagle Medium (DMEM), supplemented with Glutamax (GIBCO/BRL, USA, Cat No. 10564-011) and 10\% heat inactivated FBS (GIBCO, Cat No. 16140071), $200 \mu \mathrm{g} / \mathrm{mL}$ Penicillin, $200 \mu \mathrm{g} / \mathrm{mL}$ streptomycin, $400 \mu \mathrm{g} / \mathrm{mL}$ neomycin (GIBCO, Cat No. 15640-055), $5 \mu \mathrm{g} / \mathrm{mL}$ amphotericin, $0.05 \mathrm{mM}$ 2 - $\beta$-mercaptoethanol, and $1 \mathrm{mM}$ sodium pyruvate (all from Sigma Chemical Co, Saint Louis, MO, USA, Cat No. A9528-50MG, M7522-100ML, S8636-100ML, respectively). Cells were maintained at $37{ }^{\circ} \mathrm{C}$ with $5 \% \mathrm{CO}_{2}$ atmosphere.

\section{Cell viability test}

To determine the effects of extracts on HepG2 cells, cell viability was tested using the MTT (3-(4,5-dimethylthiazol-2yl)-2,5-diphenyl tetrazolium bromide $)$ method $^{20}$. Cells $\left(5 \times 10^{4}\right.$ cell/well) were treated with a concentration of $2 \mu \mathrm{g} / \mathrm{mL}$ of the extracts (the $n$-butanol extract from $T$. chrysantha was used at $1 \mu \mathrm{g} / \mathrm{mL}$ ) diluted in DMSO (final concentration $0.1 \%$ ), and incubated for 24 hours. After treatment, the medium was discarded, $200 \mu \mathrm{L}$ of DMEM medium containing $0.5 \mathrm{mg} / \mathrm{mL}$ MTT (Sigma Chemical Co, Saint Louis, MO, USA, Cat No. M2128$500 \mathrm{MG}$ ) was then added to each well. The plates were incubated for 4 hours at $37^{\circ} \mathrm{C}$ in a $5 \% \mathrm{CO}_{2}$ atmosphere. The medium was discarded and $100 \mu \mathrm{L}$ of DMSO was then added to solubilize the formazan crystals. Absorbance was measured in an ELISA microplate reader at $492 \mathrm{~nm}$ (ELx800; BioTek Instruments Inc., USA). Viability percentage was calculated based on the non-treated control. Three independent assays were performed, each one in triplicate.

\section{Nrf2 nuclear activation}

The HepG2 cell line $\left(3 \times 10^{5}\right.$ cell/well $)$ was cultured in DMEM medium using a T25 flask. The medium was discarded, and the cells were exposed at two time points ( 0 and 4 hours) to: Alpha-lipoic acid (ALA, $50 \mu \mathrm{M}$, Sigma Chemical Co, Saint Louis, MO, USA, Cat No. T1395-1G), Curcumin (CUR, 15 $\mu \mathrm{M}$, Sigma Chemical Co, Saint Louis, MO, USA, Cat No. C7727-500MG $)^{21-24}$, ethyl acetate extracts from $T$. chrysantha $(0.5 \mu \mathrm{g} / \mathrm{mL})$, ethyl acetate extract from $T$. rosea $(1 \mu \mathrm{g} / \mathrm{mL})$ and $\mathrm{H}_{2} \mathrm{O}_{2}(0.6 \mathrm{mM})$. After exposure, cells were harvested and used for nuclear and cytosolic protein extraction simultaneously, following the specifications included in the Nuclear Extraction Kit (Cayman Chemical, Ann Arbor MI, USA, Item No 10009277). Protein fractions were quantified using the BCA Protein Quantification Kit (Abcam, Cambridge, UK, ab102536). Nrf2 was detected by using the Nrf2 transcription factor assay kit (Cayman Chemical, Ann Arbor MI, USA, Item No 600590), and following the manufacturer's instructions. The absorbance of each well was measured at $450 \mathrm{~nm}$ in an ELx800 BioTek microplate reader.

qRT-PCR assays

HepG2 cells $\left(3 \times 10^{5}\right.$ cells/well $)$ were treated with ALA $(50 \mu \mathrm{M})$, CUR $(15 \mu \mathrm{M}$, ethyl acetate extract from $T$. chrysantha $(0.5 \mu \mathrm{g} / \mathrm{mL})$, ethyl acetate extract from $T$. rosea $(1 \mu \mathrm{g} / \mathrm{mL})$ and $\mathrm{H}_{2} \mathrm{O}_{2}(0.6 \mathrm{mM})$ for durations of 0,6 and 12 hours. After treatment, mRNA extraction was performed using the RNeasy Plus Mini Kit (Qiagen, Maryland, USA, Cat No. 74134). The mRNA was quantified with a NanoDrop 2000c (Thermo Fisher Scientific, Waltham, MA). The expression of the NQO1 gene (an Nrf2-dependent gene containing ARE sequences in its promoter region $^{25,26}$ that is expressed in response to oxidative stress) was evaluated by qRT-PCR and quantified using the $2^{-\Delta \Delta \mathrm{Ct}}$ method, using predesigned TaqMan Gene Expression Assays (code Hs00168547, Applied Biosystems, Foster City, CA, Cat No. 4331182) and the TaqMan® RNA-to-CT ${ }^{\mathrm{TM}}$ 1-Step kit (Applied Biosystems, Foster City, CA, Cat No. 4392653). The run method was holding $48{ }^{\circ} \mathrm{C}$ and $15 \mathrm{~min}, 95{ }^{\circ} \mathrm{C} 10 \mathrm{~min}$ and cycling (40 cycles) $95{ }^{\circ} \mathrm{C} 15 \mathrm{sec}, 60{ }^{\circ} \mathrm{C} 1 \mathrm{~min}$. Beta-actin was used as an endogenous control.

\section{Statistical analysis}

Each experiment was performed at least in duplicate. Results were expressed as the mean $\pm \mathrm{SD}$ of at least three independent experiments. Statistical analysis was performed using the Kruskal-Wallis test and a $p$-value less than 0.05 was considered statistically significant. The statistical tests were applied using GraphPad Prism, version 5.02 (GraphPad Software, San Diego, CA, USA).

\section{Results}

Preliminary phytochemical screening, total phenolic content, ORAC and cell viability

The preliminary phytochemical screening of the inner bark extracts obtained from $T$. rosea and $T$. chrysantha did show the presence of anthrones, quinones and coumarins, as previously reported for T. rosea ${ }^{6}$ (Table 1). Sesquiterpenic lactones were present in the $n$-hexane, chloroform and ethyl acetate extracts of $T$. rosea, but were absent from the $n$-hexane extract from T. chrysantha. Steroids were identified in chloroform and ethyl acetate extracts of both species. The presence of flavonoids and phenolic acids was observed only in the ethyl acetate extract from $T$. rosea. The total phenolic content in the extracts was determined by the Folin Ciocalteu colorimetric method. The ethyl acetate extracts obtained from $T$. rosea and $T$. chrysantha exhibited the highest total phenolic content $(2.18 \pm 0.29$ and $2.08 \pm 0.72 \mathrm{mg} \mathrm{GAE} / \mathrm{g}$ extract, respectively), whereas the chloroform and aqueous extracts displayed the lowest phenolic content $(0.63 \pm 0.11,1.55 \pm 0.78,-0.668 \pm 0.23$ and 0.07 $\pm 0.03 \mathrm{mg} \mathrm{GAE} / \mathrm{g}$ extract, respectively). The total phenolic content of the ethyl acetate extract from $T$. rosea was significantly higher $(p<0.05)$ than its chloroform extract. The order of total phenolic content in both species is: ethyl acetate $>n$-butanol> chloroform $>$ aqueous (Table 2). The ORAC results indicated that the ethyl acetate extracts from $T$. rosea, at a concentration 
Table 1. Preliminary phytochemical screening of extracts obtained from the inner bark of T. rosea and $T$. chrysantha.

\begin{tabular}{|c|c|c|c|c|c|c|}
\hline \multirow{2}{*}{$\begin{array}{l}\text { Part of the } \\
\text { plant }\end{array}$} & \multirow{2}{*}{ Extract } & \multicolumn{5}{|c|}{ Reagent } \\
\hline & & $\mathrm{AlCl}_{3}$ & KOH/EtOH & Oleum & $\mathrm{FeCl}_{3}$ & Liebermann-Burchard \\
\hline \multirow{4}{*}{$\begin{array}{l}\text { Inner bark } \\
\text { T. rosea }\end{array}$} & n-hexane & - & + & + & - & + \\
\hline & Chloroform & - & + & + & - & + \\
\hline & Ethyl acetate & - & + & + & + & + \\
\hline & n-butanol & - & + & - & - & - \\
\hline \multirow{4}{*}{$\begin{array}{c}\text { Inner bark } \\
\text { T. chrysantha }\end{array}$} & n-hexane & - & - & - & - & - \\
\hline & Chloroform & + & + & + & - & + \\
\hline & Ethyl acetate & + & + & + & - & + \\
\hline & n-butanol & + & + & - & + & - \\
\hline
\end{tabular}

+: Presence of compounds; -: Absence of compounds; $\mathrm{KOH}$ : Potassium hydroxide; $\mathrm{AlCl}_{3}$ : Aluminum chloride; $\mathrm{FeCl}_{3}$ : Ferric chloride.

Table 2. Total phenolic content, ORAC activity and cell viability in extracts obtained from the inner bark obtained from $T$. chrysantha and $T$. rosea.

\begin{tabular}{|c|c|c|c|c|}
\hline \multicolumn{2}{|c|}{ Extract } & $\begin{array}{l}\text { Phenolic content } \\
\text { (mg GAE/g extract) }\end{array}$ & $\begin{array}{c}\text { ORAC } \\
(\mu \mathrm{mol} T E / g \text { extract) }\end{array}$ & $\begin{array}{l}\text { Cell viability } \\
\text { (\%) }\end{array}$ \\
\hline \multirow{5}{*}{ T. rosea } & n-Hexane & ND & $1,631.13 \pm 285.52$ & $90.55 \pm 5.62$ \\
\hline & $\mathrm{CHCl}_{3}$ & $0.63 \pm 0.11$ & $5,794.01 \pm 586.42$ & $90.77 \pm 6.05$ \\
\hline & AcOEt & $2.18 \pm 0.29^{*}$ & $12,523.41 \pm 840.46^{* * *}$ & $93.64 \pm 5.88$ \\
\hline & Butanol & $0.91 \pm 0.10$ & $7,539.69 \pm 851.01$ & $95 \pm 7.47$ \\
\hline & $\mathrm{H}_{2} \mathrm{O}$ & $-0.66 \pm 0.23$ & $1,236.89 \pm 332.45$ & $92.33 \pm 4.97$ \\
\hline \multirow{5}{*}{ T. crysantha } & n-Hexane & ND & $237.79 \pm 402.29$ & $89.28 \pm 14.9$ \\
\hline & $\mathrm{CHCl}_{3}$ & $1.55 \pm 0.78$ & $4,124.98 \pm 474.52$ & $96.05 \pm 7.52$ \\
\hline & $\mathrm{AcOEt}$ & $2.08 \pm 0.72$ & $6,325.74 \pm 1,057.14$ & $91.99 \pm 8.13$ \\
\hline & Butanol & $2.01 \pm 0.18$ & $5,103.54 \pm 1,151.73$ & $89.66 \pm 3.18$ \\
\hline & $\mathrm{H}_{2} \mathrm{O}$ & $0.07 \pm 0.03$ & $475.56 \pm 498.68$ & $94.16 \pm 8.82$ \\
\hline \multirow{2}{*}{ Control } & Luteolin & nd & $10,426.71 \pm 2,761.28$ & nd \\
\hline & Quercetin & nd & $8,175.36 \pm 444.86$ & nd \\
\hline
\end{tabular}

TE: Trolox equivalents; GAE: Gallic acid equivalents; nd: Not determined. All experiments were carried out in triplicate, and the data represent the mean \pm SD. Kruskal Wallis ${ }^{*} p<0.05,{ }^{* * *} p<0.001$.

of $10 \mu \mathrm{g} / \mathrm{mL}$, have the best antioxidant activity $(12,523.41 \pm$ $840.46 \mu \mathrm{mol} \mathrm{TE} / \mathrm{g}$ extract) and even this activity was superior to that obtained with the controls, showing a significant difference $(p<0.05)$ in the antioxidant activity of quercetin (Table 2). Both the chloroform and $n$-butanol extracts from $T$. rosea also showed important activity. Among the T. chrysantha extracts, the ethyl acetate extract displayed the best antioxidant activity $(6,325.74 \pm 1,057.14 \mu \mathrm{mol} \mathrm{TE} / \mathrm{g}$ extract); however, this activity did not exceed that obtained with luteolin and quercetin (Table 2). The MTT assay revealed that neither the extracts from the inner bark of $T$. rosea nor those from $T$. chrysantha affected the viability of the cells studied, since viability was greater than $80 \%$ after 24 hours of exposure (Table 2).
Effect of $T$. rosea and T. chrysantha extracts on activation and nuclear translocation of Nrf2

The Nrf2 detection test allowed for the evaluation of the ability of the extracts to activate and translocate Nrf2 to the nucleus. Nrf2 detection enabled comparisons of the basal Nrf2 status in both the cytosol and the nucleus. It also allowed for comparison of their associated changes after the exposure of HepG2 cells to the ethyl acetate extracts from $T$. chrysantha $(0.5 \mu \mathrm{g} / \mathrm{mL})$ and $T$. rosea $(1 \mu \mathrm{g} / \mathrm{mL})$, which displayed the best antioxidant activity in the ORAC assay. As shown in Figure 1, the exposure of HepG2 cells to ALA, CUR, $\mathrm{H}_{2} \mathrm{O}_{2}$, and the ethyl acetate extract from both $T$. chrysantha and T. rosea, decreased the Nrf2 levels in the cytoplasm after 4 hours of exposure. This decrease was 
measured in relation to their basal level (non-exposed cells). As expected, an increase in Nrf2 levels in the nucleus was observed after exposure to ALA, CUR, $\mathrm{H}_{2} \mathrm{O}_{2}$ and the extracts. However, significant differences were found only after exposure to ALA, CUR and, $\mathrm{H}_{2} \mathrm{O}_{2}(p<0.01)$.

\section{Effect of extracts on the expression of NQO1}

Transcriptional regulation of antioxidant response genes against oxidative stress represents a defense against cell damage. In this study, we evaluated the expression of the gene coding for the antioxidant enzyme NQO1, which is involved in protection against oxidative stress. The level of expression of the NQO1 gene was evaluated (qRT-PCR) and quantified using the $2^{-\Delta \Delta \mathrm{Ct}}$ method. The results indicate that the ethyl acetate extract from both
T. chrysantha and T. rosea, as well as the culture of HepG2 cells in the presence of $\mathrm{H}_{2} \mathrm{O}_{2}$, significantly increased the expression levels of $N Q O 1$ after six hours of exposure $(p<0.05)$, compared to the controls ALA and CUR (Figure 2). The relative expression levels of NQO1 gene decreased significantly after 12 hours post-exposure.

\section{Discussion}

Oxidative stress is important because of its relation with a wide variety of disorders associated with an increase in the levels of oxidative markers and damaged cellular components, such as Parkinson's disease, Alzheimer's disease, Huntington's disease, amyotrophic lateral sclerosis ${ }^{21}$, premature aging, inflammatory diseases and cancer $^{27}$.

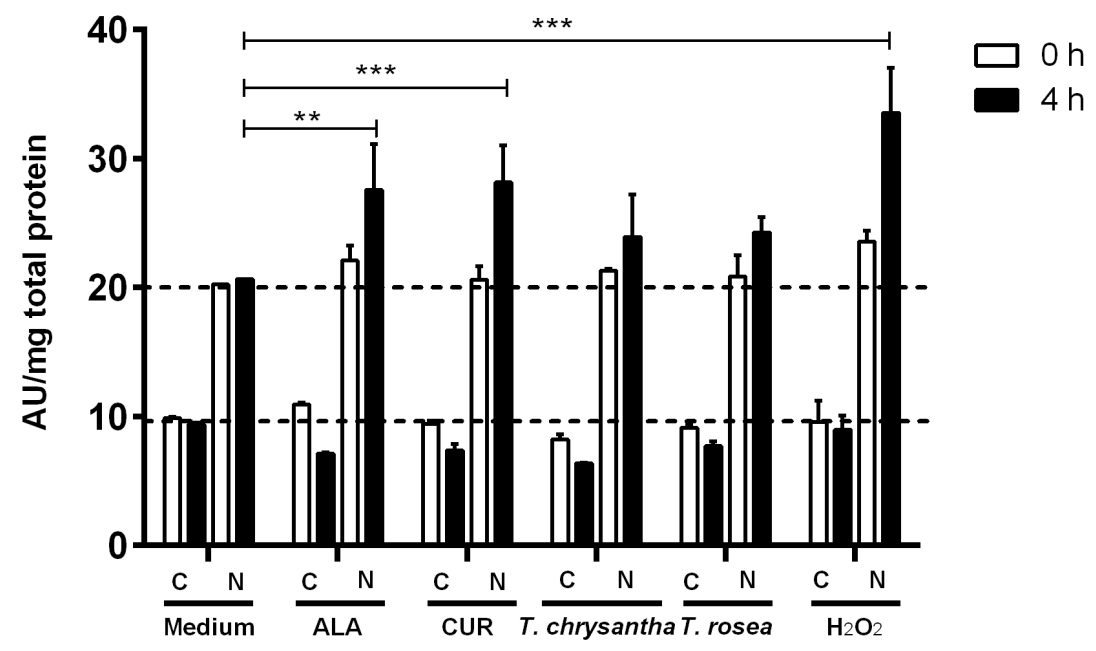

Figure 1. Nrf2 levels in cytosol (C) and nucleus (N) after 0 (white bars) and 4 hours (black bars) exposure to 50 mM ALA, 15 mM CUR, ethyl acetate extracts from $T$. chrysantha $(0.5 \mu \mathrm{g} / \mathrm{mL})$ and $T$. rosea $(1 \mu \mathrm{g} / \mathrm{mL})$ and induction of oxidative stress with $0.6 \mathrm{mM} \mathrm{H} \mathrm{O}_{2} . \mathrm{Kruskal}$ Wallis ${ }^{* *} p<0.01,{ }^{* * *} p<0.001$. ALA: Alpha-lipoic acid; CUR: Curcumin.

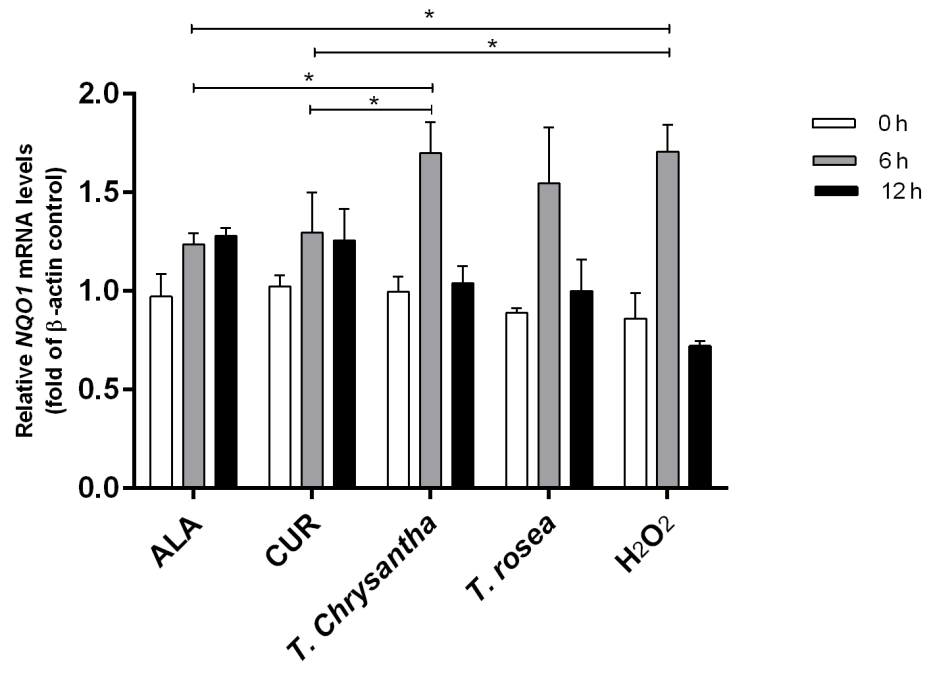

Figure 2. Relative NQO1 mRNA levels with 0,6 and 12 hours post-exposure to $50 \mathrm{mM}$ ALA, $15 \mathrm{mM}$ CUR, ethyl acetate extracts from T. chrysantha $(0.5 \mu \mathrm{g} / \mathrm{mL})$ and $T$. rosea $(1 \mu \mathrm{g} / \mathrm{mL})$ and induction of oxidative stress with $\mathbf{0 . 6} \mathrm{mM} \mathrm{H}_{2} \mathrm{O}_{2}$. Kruskal Wallis * $p<0.05$. ALA: Alpha-lipoic acid; CUR: Curcumin. 
Plants are widely used as sources of antioxidants due to their phenolic compounds and ability to scavenge ROS and free radicals, which makes them among the most potent and therapeutically useful biocompounds ${ }^{28}$. Some studies have evaluated the antioxidant activity in extracts obtained from $T$. chrysantha and $T$. rosea $^{6,29,30}$, demonstrating the potential of these plants in the search for new molecules with significant biological effects. Previous studies have also shown the potential anti-inflammatory activity of $T$. chrysantha and $T$. rosea $a^{6,30}$. Such activity can also be associated with and effect Nrf2, a molecule that not only regulates oxidative/xenobiotic stress response, but also represses inflammation by opposing transcriptional upregulation of a number of pro-inflammatory cytokine genes ${ }^{31}$. It is due to this that the antioxidant activity of the inner bark extracts obtained from $T$. chrysantha and $T$. rosea and its association with the activation-dependent translocation of Nrf2 to the nucleus and the induction in the expression of $N Q O 1$ gene was evaluated.

The ethyl acetate extracts from both $T$. chrysantha and T. rosea displayed strong antioxidant activities due to their oxygen radical absorbance capacity, which could be related to the high total phenol content found with the Folin Ciocalteu method. This capacity could also be related to phenols previously reported in T. rosea, like gentisic acid ${ }^{32}$ or phenols found in the same genus, such as $\alpha$-tocopherol and $\gamma$-tocopherol ${ }^{33}$. The results of the present study are in agreement with those previously reported for $T$. rosea ${ }^{6}$. This is the first study involving the ethyl acetate extract from T. chrysantha. An evaluation of the scavenging hydroxyl radical capacity of the methanolic and aqueous extracts from $T$. chrysantha revealed significant scavenging of the hydroxyl radical ( 80 and $83 \%$, respectively), and reductions in the production of the peroxyl radical ${ }^{30}$.

Given that ethyl acetate extracts were the most active of those produced, and that they did not affect the viability of HepG2 cells, these extracts were used to evaluate effects on Nrf2 translocation and expression of antioxidant response genes. We compared basal Nrf2 levels in both the cytosol and the nucleus, as well as the changes associated with exposure to the extracts. As expected, after 4 hours of exposure of HepG2 cells to the extracts, Nrf2 translocate from the cytoplasm to the nucleus; however, this effect was more pronounced after exposure to ALA, CUR, and $\mathrm{H}_{2} \mathrm{O}_{2}$. Flavonoids found in the ethyl acetate extract of T. rosea $^{6}$ could be related to its ability to induce the activation and translocation of $\mathrm{Nrf2}$, as they possibly have the same action mechanism as resveratrol, whose ability to activate Nrf2 translocation to the nucleus in astrocytes after 2.5 hours of exposure has been demonstrated previously ${ }^{34}$. ALA may induce $\mathrm{Nfr} 2$ translocation to the nucleus after 1 hour of treatment ${ }^{35}$. A recent study did show that pau d'arco (an extract from the inner bark of T. impetiginosa) has the capacity to activate and translocate Nrf2 to the nucleus via a MEK (MAPK/ERK kinase)-independent mechanism ${ }^{36}$. The results show that the ethyl acetate extracts obtained from $T$. chrysantha and $T$. rosea did induce the nuclear translocation of Nrf2 in HepG2 cells. Therefore, the upregulated expression of the NQO1 gene by the ethyl acetate extracts is due to the stabilization and nuclear accumulation of Nrf2.
Antioxidant activity through upregulated expression of $N Q O 1$ gene has been reported for $\beta$-lapachone ${ }^{37}$, a quinone that has previously been isolated from $T$. chrysanth ${ }^{38}$. It is also possible that steroids found within ethyl acetate extracts of $T$ rosea and $T$. chrysantha during the Lieberman-Burchard test could be responsible for the overexpression of $N Q O 1$ gene, as that has been reported for steroids like $17 \beta$-estradiol on CCD841CoN cell line ${ }^{39}$. The Nrf2 pathway is considered the most important in the cell for protection against oxidative stress, which is generated by an accumulation of ROS and/or electrophiles, leading to the oxidation of biomolecules, membrane damage, DNA adduct formation, and mutagenicity. All these changes lead to degeneration of tissues, premature aging, apoptotic cell death and the development of cancer ${ }^{13}$.

Nrf2 is a major activator of the phase II antioxidant genes such as SOD, CAT, GST, HO-1 and $\mathrm{NQOI}^{40}$. Our results demonstrated that the ethyl acetate extracts from $T$. chrysantha and $T$. rosea significantly increased the expression of NQO1 in HepG2 cells after six 6 hours of exposure compared to ALA and CUR. It has been shown that overexpression of Nrf2, by Nrf2-cDNA, upregulates the expression and induction of the $N Q O 1$ gene in response to antioxidants and xenobiotics ${ }^{41}$. In addition, Nrf2-null mice exhibited a marked decrease in $N Q O 1$ expression and induction, indicating that Nrf2 plays an essential role in the in vivo regulation of $N Q O 1$ in response to oxidative stress $^{13}$. NQO1 overexpression is also considered a cytoprotective mechanism after exposure to toxic metals ${ }^{42}$.

\section{Conclusion}

The present study indicates that the ethyl acetate extracts obtained from the inner bark of $T$. chrysantha and $T$. rosea have promising antioxidant activity, as measured by the ORAC method. Both biocompounds have the ability to activate and translocate the Nrf2 transcription factor, inducing the expression of the NQO1 gene. These results reinforce the importance of these plants in the search for new antioxidant molecules.

\section{Data availability}

Underlying data is available from Open Science Framework.

OSF: Dataset 1. Nrf2-Mediated Antioxidant Activity Tabebuia. https://doi.org/10.17605/OSF.IO/9WZ8643

Licence: CC0 1.0 Universal (CC0 1.0) Public Domain Dedication

\section{Grant information}

This study was supported by Patrimonio Autónomo Fondo Nacional de Financiamiento para la Ciencia, la Tecnología y la Innovación, Francisco José de Caldas, Contrato RC-0572-2012Bio-Red-Co-CENIVAM, Universidad Tecnológica de Pereira (Project 9-14-5), Fundación Universitaria Autónoma de las Américas and Sistema General de Regalías de Colombia (Código BPIN 2012000100050).

The funders had no role in study design, data collection and analysis, decision to publish, or preparation of the manuscript. 
1. Bittencourt NS Jr, Pereira EJ Jr, de Souza São-Thiago $P$, et al.: The reproductive biology of Cybistax antisyphilitica (Bignoniaceae), a characteristic tree of the South American savannah-like "Cerrado" vegetation. Flora - Morphology, Distribution, Functional Ecology of Plants. 2011; 206(10): 872-86. Publisher Full Text

2. Díaz F, Medina JD: Furanonaphthoquinones from Tabebuia ochracea ssp. neochrysanta. J Nat Prod. 1996; 59(4): 423-4.

Publisher Full Text

3. Gómez Castellanos JR, Prieto JM, Heinrich M: Red Lapacho (Tabebuia impetiginosa)--a global ethnopharmacological commodity? J Ethnopharmacol. 2009; 121(1): 1-13.

PubMed Abstract | Publisher Full Text

4. Gentry AH: A Synopsis of Bignoniaceae Ethnobotany and Economic Botany. Ann Mo Bot Gard. 1992; 79(1): 53-64.

Publisher Full Text

5. Gómez-Estrada H, Díaz-Castillo F, Franco-Ospina L, et al:: Folk medicine in the northern coast of Colombia: an overview. J Ethnobiol Ethnomed. 2011; 7: 27 PubMed Abstract | Publisher Full Text | Free Full Text

6. Jimenez-Gonzalez FJ, Vélez-Gomez JM, Melchor-Moncada JJ, et al:: Antioxidant, anti-inflammatory, and antiproliferative activity of extracts obtained from Tabebuia Rosea (Bertol.) DC. Pharmacogn Mag. 2018; 14(55): 25-31. Publisher Full Text

7. Jiménez-González FJ, Veloza LA, Sepúlveda-Arias JC: Anti-infectious activity in plants of the genus Tabebuia. Univ Sci (Bogota). 2013; 18(3): 257-67. Publisher Full Text

8. Sichaem J, Kaennakam S, Siripong P, et al:: Tabebuialdehydes A-C, cyclopentene dialdehyde derivatives from the roots of Tabebuia rosea. Fitoterapia. 2012; 83(8): 1456-9. PubMed Abstract | Publisher Full Text

9. Bryan HK, Olayanju A, Goldring CE, et al:: The Nrf2 cell defence pathway: Keap1dependent and -independent mechanisms of regulation. Biochem Pharmacol. 2013; 85(6): 705-17.

PubMed Abstract | Publisher Full Text

10. Taguchi K, Motohashi H, Yamamoto M: Molecular mechanisms of the Keap1Nrf2 pathway in stress response and cancer evolution. Genes Cells. 2011; 16(2): 123-40.

PubMed Abstract | Publisher Full Text

11. Dhakshinamoorthy S, Long li DJ, Jaiswal AK: Antioxidant regulation of genes encoding enzymes that detoxify xenobiotics and carcinogens. In: Earl RS Chock PB, editors. Current Topics in Cellular Regulation. Academic Press; 2001; 36 201-16.

Publisher Full Text

12. Jaiswal AK: Nrf2 signaling in coordinated activation of antioxidant gene expression. Free Radic Biol Med. 2004; 36(10): 1199-207. PubMed Abstract | Publisher Full Text

13. Kaspar JW, Niture SK, Jaiswal AK: Nrf2:INrf2(Keap1) Signaling in Oxidative Stress. Free Radic Biol Med. 2009; 47(9): 1304-9. PubMed Abstract | Publisher Full Text | Free Full Text

14. Klaassen CD, Reisman SA: Nrf2 the rescue: effects of the antioxidative/ electrophilic response on the liver. Toxicol Appl Pharmacol. 2010; 244(1): 57-65. PubMed Abstract | Publisher Full Text | Free Full Text

15. Li AN, Li S, Li HB, et al.: Total phenolic contents and antioxidant capacities of 51 edible and wild flowers. J Funct Foods. 2014: 6: 319-30. Publisher Full Text

16. Ou B, Hampsch-Woodill M, Prior RL: Development and Validation of an Improved Oxygen Radical Absorbance Capacity Assay Using Fluorescein as the Fluorescent Probe. J Agric Food Chem. 2001; 49(10): 4619-26. PubMed Abstract | Publisher Full Text

17. Alarcón E, Campos AM, Edwards AM, et al:: Antioxidant capacity of herbal infusions and tea extracts: A comparison of ORAC-fluorescein and ORACpyrogallol red methodologies. Food Chem. 2008; 107(3): 1114-9. Publisher Full Text

18. Atala $\mathrm{E}$, Vásquez L, Speisky $\mathrm{H}$, et al:: Ascorbic acid contribution to ORAC values in berry extracts: An evaluation by the ORAC-pyrogallol red methodology. Food Chem. 2009; 113(1): 331-5.

Publisher Full Text

19. Cao G, Prior RL: [5]Measurement of oxygen radical absorbance capacity in biological samples. Methods Enzymol. Academic Press; 1999; 299: 50-62. Publisher Full Text

20. Mosmann T: Rapid colorimetric assay for cellular growth and survival: application to proliferation and cytotoxicity assays. J Immunol Methods. 1983; 65(1): 55-63.

Publisher Full Text

21. Hsu WH, Lee BH, Huang YC, et al:: Ankaflavin, a novel Nrf-2 activator for attenuating allergic airway inflammation. Free Radic Biol Med. 2012; 53(9): 1643-51. PubMed Abstract | Publisher Full Text

22. Shay KP, Michels AJ, Li W, et al.: Cap-independent Nrf2 translation is part of a lipoic acid-stimulated detoxification stress response. Biochim Biophys Acta. 2012; 1823(6): 1102-9.

PubMed Abstract | Publisher Full Text | Free Full Text
23. Balogun $\mathrm{E}$, Hoque $\mathrm{M}$, Gong $\mathrm{P}$, et al:: Curcumin activates the haem oxygenase-1 gene via regulation of $\mathrm{Nrf2}$ and the antioxidant-responsive element. Biochem J. 2003; 371(Pt 3): 887-95.

PubMed Abstract | Publisher Full Text | Free Full Text

24. Yap WH, Khoo KS, Ho ASH, et al:: Maslinic acid induces HO-1 and NOQ1 expression via activation of Nrf2 transcription factor. Biomedicine \& Preventive Nutrition. 2012; 2(1): 51-8.

Publisher Full Text

25. Koriyama $\mathrm{Y}$, Kamiya M, Takadera $\mathrm{T}$, et al:: Protective action of nipradilol mediated through S-nitrosylation of Keap1 and HO-1 induction in retina ganglion cells. Neurochem Int. 2012; 61(7): 1242-53. PubMed Abstract | Publisher Full Text

26. Huerta-Olvera SG, Macías-Barragán J, Ramos-Márquez ME, et al:: Alpha-lipoic acid regulates heme oxygenase gene expression and nuclear Nrf2 activation as a mechanism of protection against arsenic exposure in HepG2 cells. Environ Toxicol Pharmacol. 2010; 29(2): 144-9. PubMed Abstract | Publisher Full Text

27. Sosa V, Moliné T, Somoza R, et al.: Oxidative stress and cancer: an overview. Ageing Res Rev. 2013; 12(1): 376-90. PubMed Abstract | Publisher Full Text

28. Je JY, Lee DB: Nelumbo nucifera leaves protect hydrogen peroxide-induced hepatic damage via antioxidant enzymes and HO-1/Nrf2 activation. Food Funct. 2015; 6(6): 1911-8

PubMed Abstract | Publisher Full Text

29. Franco Ospina LA, Castro Guerrero JP, Ocampo Buendía YC, et al:: Actividad antiinflamatoria, antioxidante y antibacteriana de dos especies del género Tabebuia. Rev Cubana Plant Med. 2013; 18(1): 34-46.

Reference Source

30. Ospina GLF, Aragón NDM, Vergel NE, et al:: Anti-inflammatory and antioxidant activities of Phenax rugosus (POIR.) WEDD and Tabebuia chrysanta G. NICHOLSON. Vitae. 2011; 18(1): 49-55.

Reference Source

31. Kobayashi EH, Suzuki T, Funayama R, et al.: Nrf2 suppresses macrophage inflammatory response by blocking proinflammatory cytokine transcription. Nat Commun. 2016; 7: 11624

PubMed Abstract | Publisher Full Text | Free Full Text

32. Griffiths LA: On the Distribution of Gentisic Acid in Green Plants. J Exp Bot. 1959; 10(3): 437- 42 Publisher Full Text

33. Pires TC, Dias MI, Calhelha RC, et al.: Bioactive Properties of Tabebuia impetiginosa-Based Phytopreparations and Phytoformulations: A Comparison between Extracts and Dietary Supplements. Molecules. 2015; 20(12): 22863-71. PubMed Abstract | Publisher Full Text

34. Erlank $\mathrm{H}$, Elmann $\mathrm{A}$, Kohen $\mathrm{R}$, et al.: Polyphenols activate Nrf2 in astrocytes via $\mathrm{H}_{2} \mathrm{O}_{2}$, semiquinones, and quinones. Free Radic Biol Med. 2011; 51(12): 2319-27. PubMed Abstract | Publisher Full Text

35. Koriyama $Y$, Nakayama $Y$, Matsugo $S$, et al: Protective effect of lipoic acid against oxidative stress is mediated by Keap1/Nrf2-dependent heme oxygenase-1 induction in the RGC-5 cellline. Brain Res. 2013; 1499: 145- 57. PubMed Abstract | Publisher Full Text

36. Richter M, Winkel AF, Schummer D, et al: Pau d'arco activates Nrf2-dependent gene expression via the MEK/ERK-pathway. J Toxicol Sci. 2014;39(2): 353-61. PubMed Abstract | Publisher Full Text

37. Park JS, Lee YY, Kim J, et al:: $\beta$-Lapachone increases phase II antioxidant enzyme expression via NQ01-AMPK/PI3K-Nrf2/ARE signaling in rat primary astrocytes. Free Radic Biol Med. 2016; 97: 168-78. PubMed Abstract | Publisher Full Text

38. Burnett AR, Thomson RH: Naturally occurring quinones. Part XII. Extractives from Tabebuia chrysantha nichols and other bignoniaceae. J Chem Soc. 1968 850-3. Publisher Full Text

39. Son $\mathrm{HJ}$, Kim $\mathrm{N}$, Song $\mathrm{CH}$, et al:: 17ß-Estradiol reduces inflammation and modulates antioxidant enzymes in colonic epithelial cells. Korean J Intern Med.

PubMed Abstract | Publisher Full Text

40. Chen B, Lu Y, Chen $\mathrm{Y}$, et al:: The role of Nrf2 in oxidative stress-induced endothelial injuries. J Endocrinol. 2015; 225(3): R83-R99. PubMed Abstract | Publisher Full Text

41. Venugopal R, Jaiswal AK: Nrf1 and Nrf2 positively and c-Fos and Fra1 negatively regulate the human antioxidant response element-mediated expression of NAD(P)H:quinone oxidoreductase, gene. Proc Natl Acad Sci U S A. 1996; 93(25) 14960-5

PubMed Abstract | Publisher Full Text | Free Full Text

42. Amara IE, EI-Kadi AO: Transcriptional modulation of the NAD(P)H:quinone oxidoreductase 1 by mercury in human hepatoma HepG2 cells. Free Radic Biol Med. 2011; 51(9): 1675-85.

PubMed Abstract | Publisher Full Text

43. Sepúlveda-Arias JC: Nrf2-Mediated Antioxidant Activity Tabebuia. 2018. http://www.doi.org/10.17605/OSF.IO/9WZ86 


\section{Open Peer Review}

\section{Current Peer Review Status:}

\section{Version 1}

Reviewer Report 23 January 2019

https://doi.org/10.5256/f1000research.18765.r42265

(c) 2019 Quesada S. This is an open access peer review report distributed under the terms of the Creative Commons Attribution License, which permits unrestricted use, distribution, and reproduction in any medium, provided the original work is properly cited.

\section{Silvia Quesada}

Department of Biochemistry, School of Medicine, University of Costa Rica (UCR), San Pedro, Montes Oca, Costa Rica

This article presents the preliminary phytochemical screening, total phenolic content and ORAC activity of different extracts obtained from the inner bark of Tabebuia rosea and T. chrysantha. The goal of the article is to study if the antioxidant activity of ethyl acetate extracts is mediated by Nrf2 nuclear translocation and its induction of antioxidant response gene (NQO1).

The methodology as the results are clearly presented with enough detail to allow replication by others. Both ethyl acetate extracts present similar total phenolic content, however T. rosea ORAC activity is almost twice $T$. chrysantha activity. Also both extracts showed a similar preliminary phytochemical screening, with a little difference; $T$. rosea showed a positive $\mathrm{FeCl}_{3}$ test but a negative $\mathrm{AlCl}_{3}$, otherwise $T$. chrysantha presented a negative $\mathrm{FeCl}_{3}$ test but a positive $\mathrm{AlCl}_{3}$. Is this difference important?

In the tests: Nrf2 activation and expression of NQO1, I think you should explain the purpose of using $\mathrm{H}_{2} \mathrm{O}_{2}$.

Please find an annotated copy of the article here for further suggestions and comments.

Is the work clearly and accurately presented and does it cite the current literature? Yes

Is the study design appropriate and is the work technically sound? Yes

Are sufficient details of methods and analysis provided to allow replication by others? Yes

If applicable, is the statistical analysis and its interpretation appropriate? 
Yes

Are all the source data underlying the results available to ensure full reproducibility? Yes

Are the conclusions drawn adequately supported by the results?

Yes

Competing Interests: No competing interests were disclosed.

Reviewer Expertise: Biological activities of plants and fruits extracts, especially anti-inflammatory, antioxidant and cytotoxic activities.

I confirm that I have read this submission and believe that I have an appropriate level of expertise to confirm that it is of an acceptable scientific standard.

Author Response 05 Feb 2019

Juan Carlos Sepúlveda-Arias, Universidad Tecnológica de Pereira, Pereira, Colombia

Dear Dr. Quesada. Thank you very much for your evaluation. We included in the manuscript that $\mathrm{H}_{2} \mathrm{O}_{2}$ was used as an oxidative stress inductor. We also included in the new version the suggestions you highlight in the PDF.

Competing Interests: No competing interests were disclosed.

Reviewer Report 09 January 2019

https://doi.org/10.5256/f1000research.18765.r42264

(C) 2019 Martin-Franco J. This is an open access peer review report distributed under the terms of the Creative Commons Attribution License, which permits unrestricted use, distribution, and reproduction in any medium, provided the original work is properly cited.

\section{Jaime Martin-Franco}

Grupo de investigación Química de Productos Naturales QPN, Departamento de Química, Universidad del Cauca, Popayán, Colombia

Tabebuia is the largest genus of the Bignoniaceae family and several bioactive compounds such as: naphthoquinones; quinones and phenols have been extracted so far, due to the traditional use of numerous species of this genus. Very few studies have evaluated the anti-oxidant activity of extracts obtained from both $T$. rosea and $T$. chrysantha and only one study has evaluated the effect of $T$. impetiginosa extracts on Nrf-2 activation and translocation.

The study from Garzón-Castaño et al. describes for the first time the effect of the inner bark extracts from $T$. rosea and $T$. chrysantha on the Nrf-2-mediated antioxidant activity. The best 
antioxidant activity (evaluated using the ORAC Technique) was displayed by the ethyl acetate extracts from both species. This activity was clearly associated with the activation and translocation of Nrf-2 to the nucleus and the induction in the expression of the NQO1 gene in HepG2 cells. This study contributes to the knowledge on the biological activity of plants from the genus Tabebuia that have not been studied extensively and highlight its importance on the search of new molecules with antioxidant activity.

Finally, the research paper is very clear and presents results of great expectation.

Is the work clearly and accurately presented and does it cite the current literature?

Yes

Is the study design appropriate and is the work technically sound?

Yes

Are sufficient details of methods and analysis provided to allow replication by others?

Yes

If applicable, is the statistical analysis and its interpretation appropriate?

Yes

Are all the source data underlying the results available to ensure full reproducibility? Yes

Are the conclusions drawn adequately supported by the results?

Yes

Competing Interests: No competing interests were disclosed.

Reviewer Expertise: Natural Products and free radical

I confirm that I have read this submission and believe that I have an appropriate level of expertise to confirm that it is of an acceptable scientific standard. 
The benefits of publishing with F1000Research:

- Your article is published within days, with no editorial bias

- You can publish traditional articles, null/negative results, case reports, data notes and more

- The peer review process is transparent and collaborative

- Your article is indexed in PubMed after passing peer review

- Dedicated customer support at every stage

For pre-submission enquiries, contact research@f1000.com 